\title{
INKUNABUL W OPRAWIE Z SUPEREKSLIBRISAMI BISKUPA JANA LUBRAŃSKIEGO NA TLE INTROLIGATORSTWA KRAKOWSKIEGO I POZNAŃSKIEGO KOŃCA XV - POCZĄTKU XVI WIEKU
}

Biskup Jan Lubrański (1449-1520) zgodnie zaliczany jest w poczet najświatlejszych postaci Kościoła polskiego początków XVI w. ${ }^{1}$ Źródeł jego rozległych, humanistycznych zainteresowań należy upatrywać w pobycie na uniwersytetach w Krakowie (1472-1477), a następnie Bolonii (1478-1480/1481) i Rzymie (1481), gdzie miał okazję zetknąć się z przedstawicielami intelektualnej elity renesansowej Italii. Ich uwieńczeniem stało się założenie przez biskupa w ostatnim roku życia słynnej Neoacademii w Poznaniu, której program kształcenia oparty był m.in. na znajomości literatury antycznej oraz eloquentii, rozumianej jako umiejętność wypowiedzi wedle wzorców starożytnych ${ }^{2}$.

Humanistycznym zainteresowaniom J. Lubrańskiego towarzyszyła miłość do ksiąg, wyrazem której było stworzenie prywatnego księgozbioru, liczącego w momencie śmierci dygnitarza co najmniej 151 dzieł drukowanych i rękopiśmiennych ${ }^{3}$. Pierwsze znaczące nabytki miały miejsce zapewne już w okresie stu-

* Arkadiusz Wagner - dr bibliologii i historii sztuki, adiunkt w Instytucie Informacji Naukowej i Bibliologii UMK w Toruniu; e-mail: wagner@umk.pl

${ }^{1}$ Zob. np.: L. Hajdukiewicz, Lubrański Jan h. Godziemba, w: Polski Słownik Biograficzny, t. 17, Wrocław-Warszawa-Kraków-Gdańsk 1973, s. 81-84 (tamże bibliografia); J. Pakulski, Krag rodzinny Jana Lubrańskiego, „Kronika Miasta Poznania” (dalej: KMP), 2 (1999) s. 28-43.

${ }^{2}$ Zob np.: D. Żołądź-Strzelczyk, Academia Lubransciana (1519-1780). Dzieje szkoły od powstania do czasów Komisji Edukacji Narodowej, KMP, 2 (1999) s. 141-151. S. Łempicki wysuwa przypuszczenie, że Lubrański zakładając swą szkołę mógł się wzorować na Neacademii Alda Manucjusza w Wenecji, zob.: tenże, Polskie koneksje dynastii Manucjuszów, w: tegoż, Renesans i humanizm w Polsce. Materiały do studiów, Warszawa 1952, s. 49-50. O tym, że biskup nigdy nie znalazł się w ścisłym gronie jej członków przekonuje M. Rokosz, Wenecka oficyna Alda Manucjusza i Polska w orbicie jej wplywów, Wrocław 1982, s. 182-184.

${ }^{3}$ Acta capitulorum saeculi XVI selecta, T. I, wyd. B. Ulanowski, Kraków 1894, s. 219-221; A. Lewicka-Kamińska, Renesansowy księgozbiór Mikołaja Czepla w Bibliotece Jagiellońskiej, Wrocław 1956, s. 28-29; L. Hajdukiewicz, Księgozbiór i zainteresowania bibliofilskie Piotra Tomickiego na tle jego działalności kulturalnej, Wrocław-Warszawa-Kraków 1961, s. 23, 140; J. Perzy- 
diów, po których najprawdopodobniej następowały zakupy w kraju i zagranicą, jak również dary. Dzięki zachowanemu inwentarzowi ksiąg zastanych w pałacu biskupa w dzień po jego zgonie, możliwe jest przybliżone określenie ich danych bibliograficznych lub przynajmniej zawartości treściowej ${ }^{4}$ I tak, dominującą pozycję w księgozbiorze zajmowały włoskie edycje dzieł autorów starożytnych, zarówno greckich (np. Homer, Ksenofont), jak i rzymskich, w tym dzieła literackie (np Plaut, Juliusz Cezar, Cyceron, Wergiliusz, Horacy), historiograficzne (np Plutarch, Tacyt, Józef Flawiusz), prawnicze, przyrodnicze, czy też medyczne. Okazale prezentował się również dorobek włoskich humanistów, zwłaszcza w zakresie filologii i filozofii oraz komentarzy do prac starożytnych. Z racji funkcji kościelnych i państwowych J. Lubrański posiadał też księgi religijne i liturgiczne, pomiędzy którymi na uwagę zasługuje choćby Brewiarz Poznański wydany z jego inicjatywy, jak również księgi dotyczące prawa i historii Królestwa Polskiego oraz Prus.

Mimo wspomnianych informacji źródłowych, pozwalających na ogólną rekonstrukcję czytelniczych upodobań J. Lubrańskiego, nasza wiedza o jego stosunku do książki jest jednak bardzo szczupła. Wynika to przede wszystkim z zaginięcia bądź - co nie mniej prawdopodobne - zniszczenia niemal całego jego księgozbioru. W świetle dotychczasowej literatury fachowej do dziś zachowały się bowiem zaledwie trzy należące do niego księgi, przy czym proweniencja jednej $\mathrm{z}$ nich poddawana jest w wątpliwość ${ }^{5}$. Zgodnie z pierwszą z hipotez dotyczących losów ksiąg hierarchy, po jego śmierci niemal wszystkie zostały przejęte przez kapitułę katedralną i wcielone do biblioteki kapitulnej ${ }^{6}$. Tamże mogło nastąpić ich wstępne rozproszenie wskutek niekontrolowanego wypożyczania ksiąg przez księży ${ }^{7}$. Na lata po śmierci biskupa przypada ogólne zaniedbanie biblioteki, potwierdzane orzeczeniami kapituły o „książkach przysypanych prochem” i ,próchniejących"8. W takim stanie bibliotekę zastał potop szwedzki, podczas którego zagrabiono bliżej nieokreśloną liczbę druków i manuskryptów. Dzieła, które potencjalnie mogły zostać na miejscu, w 1781 r. przekazane zostały wraz z późniejszymi nabytkami bibliotecznymi do seminarium duchownego w Poznaniu, które sprawowało pieczę nad katedralnym księgozbiorem do 1926 r. Jednakże w mię-

na, Lubrański Jan, w: Słownik pracowników ksiązki polskiej. Suplement, Warszawa-Łódź 1986, s. 124 (autorka pisze o „ok. 170 poz.”); A. Ochmańska, Prywatne księgozbiory wielkopolskie XVI w., „Biblioteka”, 2 (1998) s. 23-24, 27, 32-34; R. Marciniak, Biblioteka biskupa Jana Lubrańskiego, KMP, 2 (1999) s. 111-126.

${ }^{4}$ Acta capitulorum saeculi XVI selecta, s. 219-221; Marciniak, Biblioteka, s. 112-120; A. Ochmańska, Księgozbiór i zainteresowania bibliofilskie biskupa poznańskiego Jana Lubrańskiego, „Biblioteka”, 5 (2001) s. 7-16.

${ }^{5}$ J. Rył, Katalog inkunabułów zespołu seminaryjnego Biblioteki Katedralnej w Gnieźnie, „Archiwa, Biblioteki i Muzea Kościelne” (dalej: ABMK), 25 (1972) s. 156/kat. 184, s. 171/kat. 263; Marciniak, Biblioteka, s. 122-123

${ }^{6}$ M. Wojciechowska, Z dziejów książki w Poznaniu w XVI wieku, Poznań 1927, s. 94-95; Hajdukiewicz, Lubrański, s. 83; Marciniak, Biblioteka, s. 120-121.

${ }^{7}$ Wojciechowska, $Z$ dziejów, s. 95 (wg akt kapitulnych).

${ }^{8}$ Tamże, s. 95-96 (wg akt kapitulnych). 
dzyczasie wiele - a może wszystkie? - zachowane w nim księgi biskupie mogły zostać unicestwione w wyniku decyzji o likwidacji 48 cetnarów(!) najstarszych ksiąg seminaryjnych, mających ustąpić miejsca nowej literaturze naukowej. W efekcie, gdy w 1918 r. opracowywano inwentarz ksiąg z XV w. ze zbiorów seminaryjnych, okazało się, że z dawnego zasobu kapituły pochodzą zaledwie dwa inkunabuły, wśród których żaden nie nosił śladów przynależności do zbioru bpa J. Lubrańskiego. Dzieło zniszczenia dopełniło się podczas II wojny światowej, kiedy to kilkadziesiąt tysięcy starych druków z Archiwum Archidiecezjalnego w Poznaniu (spadkobiercy księgozbioru seminaryjnego) uległo zniszczeniu w składnicy książek utworzonej przez Niemców. Wedle innej - niedawno odrzuconej - hipotezy J. Lubrański przepisał książki z prywatnej biblioteki na rzecz założonej przez siebie Akademii, co też rzekomo zostało zrealizowane przez kapitułę ${ }^{9}$. Po rozwiązaniu Kolegium Lubrańskiego w 1780 r. bibliotekę miano przenieść do poznańskiego Gimnazjum św. Marii Magdaleny, a stamtąd - w okresie międzywojennym - do Biblioteki Uniwersyteckiej w Poznaniu. Czy tak się faktycznie stało, a jeśli tak, to czy wśród ksiąg pokolegialnych znajdowały się lubransciana, nie sposób dziś stwierdzić. W czasie wojny bowiem także część najcenniejszych zasobów Biblioteki Uniwersyteckiej uległa zatraceniu, w efekcie czego aktualna kartoteka proweniencji tej placówki nie wykazuje ksiąg J. Lubrańskiego. Konsekwencją powyższego status quo jest niemal zupełny brak wiedzy o szacie zewnętrznej księgozbioru poznańskiego dostojnika, a także o sposobach oznaczania przez niego własności woluminów. Określenie tego pozwoliłoby zaś znacząco rozjaśnić obraz bpa J. Lubrańskiego jako humanistycznego bibliofila, w tym zwłaszcza określić choćby w przybliżeniu gdzie, u kogo i jakie oprawy zamawiał do swych książek, a także jaką formę znaku własnościowego preferował.

Jak bowiem dowodzi poniższa statystyka, idea manifestacji własności książki była Lubrańskiemu bliska: spośród trzech dotąd zidentyfikowanych egzemplarzy jego ksiąg, aż dwie zostały oznaczone ekslibrisami malowanymi (protoekslibrisami). Pierwszy z nich, ukazany jest na dolnym marginesie jednej z kart inkunabułu z Epistolae św. Hieronima (pars I-II, Roma 1476 i 79) ze zbiorów Biblioteki Kapitulnej (dzisiejszego Archiwum Archidiecezjalnego) w Gnieźnie ${ }^{10}$. Składa się on z herbu Lubrańskich - Godziemby, pod infułą, krzywaśnią pastorału i pasami vittae, otoczonymi prostokątną ramką z motywami kwiatów o akantopodobnym ulistnieniu. Forma drugiego ekslibrisu typowa jest już niemal bez reszty dla rene-

\footnotetext{
${ }^{9}$ K. Mazurkiewicz, Poczatki Akademii Lubrańskiego w Poznaniu (1519-1535), Poznań 1921, s. 9-10; Ochmańska, Prywatne, s. 1718; Marciniak, Biblioteka, s. 121-122; B. Bieńkowska, Ksiązka na przestrzeni dziejów, Warszawa 2005, s. 99, 335. Poszlaką, że przed śmiercią biskupa część jego księgozbioru mogła być uznana za szczególnie przydatną dla dydaktyki Akademii i przemieszczona do nieznanego dziś lokum, jest brak licznych, fundamentalnych dzieł filozofii antycznej i średniowiecznej wśród ksiąg zinwentaryzowanych w jego pałacu (wzmiankuje o tym Marciniak, Bibliote$k a$, s. 116). Trudno zaś przyjąć, że publikacje z tego zakresu - niezależnie od osobistych zainteresowań Lubrańskiego - zostały przez niego zignorowane, zwłaszcza wobec długoletnich przygotowań do założenia humanistycznej akademii. O tym, że księgozbiór biskupi był zasobniejszy niżby wskazywał inwentarz, przekonuje też Rokosz, Wenecka, s. 198-199, 258-259.

${ }^{10}$ Rył, Katalog, s. 156/kat. 184; Marciniak, Biblioteka, s. 122.
} 
sansu, o czym przesądza zarówno sposób jego namalowania jak i ikonografia otaczającej dekoracji. Ukazany jest on pośrodku dolnej części bordiury w kształcie prostokątnej ramki z ornamentami kandelabrowymi i motywami groteskowymi, otaczającej antykwowy tekst włoskiego inkunabułu De animalibus Arystotelesa (Wenecja 1476) ${ }^{11}$. Na tarczy herbowej o charakterystycznym, późnogotyckim kroju, widnieje godło Godziemba, nad nią - infuła i pasy vittae, po bokach zaś postaci trytonów jako heraldycznych trzymaczy.

Powyższa formuła oznaczania własności lub donacji ksiąg była w XV i na początku XVI w. bardzo popularna wśród europejskich bibliofilów. O ile na północ od Alp przez większość tego okresu dominował schemat tarczy herbowej w obrębie gotyckiej bordiury, to w Italii szybko rozpowszechniły się charakterystyczne typy tarcz, zwykle w antykizujących wieńcach i na tle renesansowych ornamentów $^{12}$. Motywy te zaadoptowali humanistyczni bibliofile z krajów zaalpejskich, zlecający włoskim iluminatorom namalowanie ekslibrisów w nabytych przez siebie książkach ${ }^{13}$. Do tej właśnie kategorii należy ekslibris J. Lubrańskiego, najpewniej wykonany z inicjatywy jego weneckiego przyjaciela, Mikołaja Judeka, związanego z krakowskim dworem Jagiellonów ${ }^{14}$.

Prawdopodobnie bp J. Lubrański nie oznaczał swych ksiąg ekslibrisami graficznymi. Na okres poprzedzający jego śmierć przypadają zresztą początki tej kategorii znaku własnościowego ksiąg w Polsce ${ }^{15}$. Wprawdzie pionierskie na rodzimym gruncie ekslibrisy wykonano już w 1516 i 1517 r. dla bpa włocławskiego Macieja Drzewickiego, ale w świetle dzisiejszego stanu wiedzy, aż do początku lat 20. XVI w. był to odosobniony skutek tyleż humanistycznych zapatrywań tegoż bibliofila, co bliskich relacji łączących go z drukarzem Hieronimem Wietorem $^{16}$.

Skrajne przetrzebienie księgozbioru J. Lubrańskiego nie daje też podstaw do stwierdzenia, że oznaczał swe księgi wpisami własnościowymi, bądź też zaklęciami przeciwko książkowym złodziejom. Warto jednak wspomnieć w tym kontek-

${ }^{11}$ Marciniak, Biblioteka, s. 123.

${ }^{12}$ Zob. np.: M. Salmi, La miniatura italiana, Milano 1956, tabl. XLVII, LI/b, LXX/b; A. Wagner, Nieznana oprawa dla Jana Laskiego w Bibliotece Uniwersyteckiej w Poznaniu. Przyczynek do badań nad italianizmem $w$ introligatorstwie polskim XVI wieku, „Biblioteka”, 16 (2012) s. 34, il. 5, 6.

${ }^{13}$ Najsłynniejszym wśród nich pozostaje król Węgier, Maciej Korwin, zlecający wykonanie wykwintnych rękopisów iluminowanych z protoekslibrisami wiodącym artystom włoskim, zob. np.: I. Berkovits, Corvinen Bilderhandschriften aus der Bibliothek des Königs Matthias Corvinus, Budapest 1963, tabl. I-III, IX, XXXVI, XLV; Książnica Miejska im. M. Kopernika w Toruniu. Informator, opr. A. Tujakowski, Torun 1983, tabl. 2 nie num.

${ }^{14}$ Marciniak, Biblioteka, s. 123.

${ }^{15}$ Zob. np.: M.J. Wojciechowski, Ekslibris, godło bibliofila, Wrocław 1978, s. 38-41; M. Grońska, Ekslibrisy. Wiadomości zebrane dla kolekcjonerów, Warszawa 1992, s. 26-27.

${ }^{16}$ K. Piekarski, Przyczynki do dziejów polskiego exlibrisu, „Exlibris”, V (1924) s. 1-4, tab. IV; nie jest wykluczone, że w podobnym czasie co ekslibris Drzewickiego powstał pierwszy z dwóch ekslibrisów anonimowego szlachcica herbu Rawa, zob. A. Wagner, Uwagi o znakach własnościowych z drugiej połowy XV i pierwszej ćwierci XVI wieku w inkunabułach Biblioteki Uniwersyteckiej w Poznaniu, „Biblioteka”, 17 (2013) s. 23-30, il. 8. 
ście o notce, która znajduje się na trzecim z jego inkunabułów, Missale Magdeburgense, wydanym w Magdeburgu w 1480 r. Oto bowiem na luźnej karteczce włożonej do tej księgi znajduje się napis „Istum librum persolvit Reverendissimus dominus episcopus Poznaniensis dominus Johannes de Lubranijecz" ${ }^{17}$. Z jego treści trudno jednoznacznie wywnioskować czy wykonano go przed czy po śmierci biskupa. W powiązaniu z brakiem zaopatrzonego w nią druku wśród ksiąg zinwentaryzowanych $\mathrm{w}$ pałacu biskupim, skłoniło to badaczy do powątpiewania w jego przynależność do dygnitarskich zbiorów ${ }^{18}$. Jak jednak wskazuje treść przytoczonej w dalszej części tekstu - notki w księdze J. Lubrańskiego odnalezionej we Włocławku, także i powyższy wolumin mógł być w jego posiadaniu.

Znakami własnościowymi, które pod koniec XV, a zwłaszcza na początku XVI w. zyskiwały coraz większą popularnoś,ć były też superekslibrisy wyciskane lub ryte na jednej lub obu okładzinach oprawy. I tu jednak spustoszenia poczynione przez czas w książkowej schedzie po J. Lubrańskim skłoniły przed laty - znakomitego skądinąd badacza - Ryszarda Marciniaka, do nazbyt pochopnego stwierdzenia, że biskup na pewno superekslibrisów nie stosowa $1^{19}$. Okoliczność ta przyczyniła się zresztą do poddania w wątpliwość bibliofilskiej postawy bpa J. Lubrańskiego $\mathrm{w}$,wąskim znaczeniu kolekcjonera bardziej zainteresowanego formą ksiąg niż ich treścią" 20 .

Tymczasem w 2012 r., w trakcie badań nad introligatorskimi znakami własnościowymi księgozbiorów polskich i litewskich XV-XVIII w., prowadzonych w Bibliotece Seminaryjnej we Włocławku, piszący te słowa natrafił na foliant oznaczony superekslibrisami J. Lubrańskiego ${ }^{21}$. Fakt ten skłania do bliższego przyjrzenia się temu woluminowi, wypływające z tego wnioski pozwolą bowiem na dokładniejsze zobrazowanie działalności bibliofilskiej biskupa, jednocześnie uzupełniając katalog książek zinwentaryzowanych niegdyś w jego rezydencji o kolejną, wcześniej nieznaną pozycję.

Interesująca nas księga to Biblia, cum additione Menardi monachi, wydana 4 kwietnia 1480 r. w norymberskiej oficynie Antona Kobergera (sygn.: XV. F. 1204) [il. 1] ${ }^{22}$. Naturalnie, spis ksiąg po J. Lubrańskim zawiera informacje o Biblii, jednakże na podstawie skrótowego opisu trudno stwierdzić, czy odnosi się on do włocławskiego egzemplarza ${ }^{23}$. Blok książki zszyto sześcioma zwięzami, zaakcentowanymi grubymi garbami na oprawie. Okładziny wykonano z desek bukowych (obecnie silnie zdefektowanych) o fazowanych wewnętrznych brzegach

\footnotetext{
${ }^{17}$ Marciniak, Biblioteka, s. 122.

${ }^{18}$ Rył, Katalog, s. 171/kat. 263; Marciniak, Biblioteka, s. 122.

${ }^{19}$ Marciniak, Biblioteka, s. 123.

${ }^{20}$ Tamże.

${ }^{21}$ A. Wagner, Relikt humanistycznego księgozbioru, „Spotkania z Zabytkami”, 5-6 (2013) s. $60-62$, il. $1-5$.

${ }^{22}$ Incunabula quae in bibliothecis Poloniae asservantur, moderante A. Kawecka-Gryczowa, composuerunt M. Bohonos, E. Szandorowska, I, Wratislaviae-Varsaviae-Cracoviae 1970, cat. 1011.

${ }^{23}$ Acta capitulorum saeculi XVI selecta, s. 220 (tamże przytoczone lapidarne określenie „Biblia").
} 
i pokrytych brązową skórą, zachodzącą na około połowę szerokości desek [il. 2, 3]. Przy zewnętrznej, dłuższej krawędzi górnej okładziny znajdują się dwie mosiężne zapinki tzw. okienkowe z wytłaczaną dekoracją, przedstawiającą inskrypcję majuskułową „WAR”(?), ujętą ornamentami sznurowymi ${ }^{24}$. Stanowią one pozostałość po zapięciach z mosiężnymi zaczepami na skórzanych paskach (obecnie brakującymi). Dekorację okładzin wykonano w technice ślepych oraz złoconych i srebrzonych wycisków strychulca, tłoków i radełka. Ukazuje ona kompozycję ramową ze zwierciadłem, wyznaczoną strychulcem, przy czym znacznie bogatszą formę nadano dekoracji górnej okładziny. Znajdujące się w jej centrum wąskie zwierciadło podzielone jest na trzy części, z których centralną wypełnia złoty, minuskułowy chrystogram ,ihs” w glorii składającej się z dwojakich - prostych i falujących - promieni. Od góry i dołu ujmują ją srebrzone (obecnie częściowo starte i poczerniałe) wyciski superekslibrisowe w formie późnogotyckiej tarczy z godłem Godziemba $(22 \times 24 \mathrm{~mm})$ [il. 2, 3, 5d]. Zwierciadło otacza podwójna rama, z której rama wewnętrzna wypełniona jest arabeską, zaś zewnętrzna wielopłatkowymi rozetami. W zewnętrznych narożach ramy ukazano, analogiczne jak wyżej, tarcze herbowe z Godziembą. Ponad ramą, w dwóch poziomych tzw. listwach, wyciśnięto teksturowy napis „Prima : pars : $\mid \cdot$ biblie $:: ”$. Dekoracja dolnej okładziny odznacza się większą prostotą, zarówno w zakresie kompozycji, użytych narzędzi, jak i braku złoceń. Jej centrum wyznacza wąskie zwierciadło, w którym naprzemiennie ukazano trzy superekslibrisowe herby i trzy kwiatony. Obramienie składa się z wielokrotnych (po sześć na górze i dole, po dwa na bokach) wycisków radełka z charakterystycznym, gotyckim ornamentem konarowo-liściowym oraz wkomponowanymi w niego motywami zająca i jelenia gonionych przez $\mathrm{psa}^{25}$. Dekoracja grzbietu, widniejąca w kompartymentach, ukazuje - obecnie trudno czytelne - ornamenty floralne, wyciśnięte strychulcem. Wyklejkę górnej okładziny wykonano z papieru żeberkowego oznaczonego znakiem wodnym z motywem głowy wołu pod koroną zamkniętą; znak wodny znajduje się też na antefolium: głowa wołu, na której tkwi belka opleciona przez węża i zakończona krzyżem.

Charakterystyczne rozwiązania materiałowe oraz formalno-stylowe oprawy skłaniają do postawienia kwestii miejsca i czasu jej wykonania. Biorąc pod uwagę ponad dwudziestoletnie rządy J. Lubrańskiego jako biskupa poznańskiego, rozważenia w pierwszej kolejności wymagałaby możliwość wykonania jej w stolicy Wielkopolski. Tu jednak natrafiamy na ogromne problemy wynikające ze szczątkowej znajomości dorobku lokalnych introligatorów od XV w. do przynajmniej 2. ćwierci XVI w. Wprawdzie wiadomo, że pomiędzy latami 1476 a 1483 działał tu znany z imienia introligator Mikołaj (Nicolaus), jednak zupełnie nieznana jest

${ }^{24}$ Terminologia dotycząca zapięć wg: G. Adler, Handbuch Buchverschluss und Buchbeschlag, Wiesbaden 2010, s. 21-22.

${ }^{25}$ Problem tego rodzaju ornamentu $\mathrm{w}$ introligatorstwie gotyckim oraz jego chrystologicznej wymowy symbolicznej zob. w: A. Wagner, Motywy towieckie na oprawach książkowych od średniowiecza do XVIII wieku, w: Europejskie tradycje towieckie, red. T. J. Żuchowski, Warszawa 2013, s. $149-150$, il. 5a-c. 
forma dekoracji jego dzieł ${ }^{26}$. Z przełomu XV i XVI w. pochodzi kilka opraw inkunabułów ze zbiorów Biblioteki Poznańskiego Towarzystwa Przyjaciół Nauk, wykonanych przypuszczalnie $\mathrm{w}$ warsztacie anonimowego introligatora poznańskiego współpracującego (a nie wykluczone, że tożsamego) z tamtejszym księgarzem i nakładcą, Piotrem z Lubeki ${ }^{27}$. Ich ujednoliconą dekorację oparto na kompozycjach ramowych ze zwierciadłem wypełnionym tzw. wzorem owocu granatu/pędu ruty, co upodabnia je do typowych opraw tzw. kobergerowskich. Być może owym introligatorem był Walenty - prawdopodobnie ten sam co znany z późniejszych źródeł Walenty Papież, któremu po śmierci wspomnianego księgarza w 1512 lub 1513 r. wdowa miała zapłacić za oprawę książek ${ }^{28}$. Możliwe jednak, że charakterystyczna forma opraw wiąże się z działalnością nieznanego dziś introligatora współpracującego z poznańską filią słynnej, norymberskiej firmy Antona Kobergera $^{29}$. Nieznany jest dorobek Bartłomieja z Poznania ( $† 1504$ r.) - iluminatora $\mathrm{i}$ introligatora oraz ostatniego $\mathrm{w}$ mieście kopisty ksiąg $\mathrm{g}^{30}$. Na rynku poznańskim miał on budę handlową, w której sprzedawał rękopisy i druki, a wśród nich z pewnością woluminy samodzielnie oprawione. Narzędzia introligatorskie przekazał mocą testamentu poznańskim bernardynom, co z kolei sygnalizowałoby, że także oni parali się introligatorstwem. W źródłach archiwalnych z 1513 r. ujawnia się kolejna sylwetka introligatora i zarazem bibliopoli: Jana Patruusa z Koła, który w 1520 r. przeniósł się z poznańskiego Przedmieścia św. Marcina na Chwaliszewo (obecną dzielnicę miasta), będące wówczas własnością kapituły katedralnej ${ }^{31}$. Wedle lakonicznych informacji Marii Świeżawskiej (Wojciechowskiej) w omawianym okresie było ono ruchliwym ośrodkiem introligatorstwa ${ }^{32}$, co niewątpliwie miało swój związek z bliskością kościelnej klienteli. W istocie, także Patruus zacieśnił z nią wówczas swe kontakty. Nie wiadomo wprawdzie czy sporządzał oprawy do księgozbioru bpa J. Lubrańskiego, znamienne jest jednak, że w $1521 \mathrm{r}$. - czyli już po śmierci hierarchy - otrzymał 16 złotych z biskupiej szkatuły, za oprawienie ksiąg dla klasztoru katarzynek w Poznaniu ${ }^{33}$. Niestety, oblicze formalno-stylowe jego dzieł stanowi wciąż zagadkę.

${ }^{26}$ M. Świeżawska (Wojciechowska), Introligatorzy poznańscy w wieku XVI, „Exlibris”, VII (1925) z. 1, s. 71; Wojciechowska, Z dziejów, s. 86.

${ }^{27}$ A. Wagner, Poznańskie oprawy późnogotyckie ze zbiorów PTPN-u, Instytut Historii Sztuki UAM, mps, Poznań 1999, s. 2-12, il. 1-5, 7. Zob. też: M. Wojciechowska, Z dziejów ksią̇ki w Poznaniu w XVI w., Poznań 1927, s. 2-6, 33, 39; A. Głowacka, Piotr z Lubeki, w: Słownik Pracowników Książki Polskiej, Warszawa-Łódz 1972, s. 683 (tamże bibliografia). Być może jego autorstwa są dwie oprawy ze zbiorów Archiwum Kapitulnego w Gnieźnie, reprodukowane w: L. Formanowicz, Katalog inkunabułów Biblioteki Kapitulnej w Gnieźnie, zeszyt 1, Gniezno 1939, tabl. IX-X.

${ }^{28}$ Świeżawska (Wojciechowska), Introligatorzy, s. 72; Wojciechowska, Z dziejów, s. 5-6.

${ }^{29}$ Wojciechowska, Z dziejów, s. 6-7; Encyklopedia Wiedzy o Książe (dalej: EWOK), WrocławWarszawa-Kraków 1971, szp. 1962.

${ }^{30}$ Wojciechowska, Z dziejów, s. 2, 86; EWOK, szp. 110

${ }^{31}$ Świeżawska (Wojciechowska), Introligatorzy, s. 71-72; Wojciechowska, $Z$ dziejów, s. 8-10, 18, 33, 86, tabl. genealogiczna po s. 114; C. Pilichowski, Z dziejów produkcji, handlu i kultury książki w Poznaniu u schyłku XVI w. (1570-1595), „Studia Poznańskie”, 1954, cz. II, s. 54, 60.

${ }^{32}$ Świeżawska (Wojciechowska), Introligatorzy, s. 72.

${ }^{33}$ Tamże's. 73; Marciniak, Biblioteka, s. 123 
Wśród dotąd poznanych wyrobów poznańskich introligatorów, dziełem sygnalizującym możliwość wykonania lubranscianum w tym mieście jest oprawa druku przechowywana w Bibliotece Towarzystwa Naukowego Płockiego (sygn. XVI, 737). Powstała ona w 1546 r. przypuszczalnie w warsztacie prężnego księgarza, nakładcy i introligatora, Jana Patruusa lub anonimowego introligatora związanego z jego firmą $a^{34}$. Jej dekoracja stanowi typowy przykład poznańskiego introligatorstwa 2. i 3. ćwierci XVI w.: kompozycję ramową na okładzinach $\mathrm{z}$ brązowej skóry na deskach tworzą radełkowania z motywami religijnymi i antykizującymi, które oddzielają listwy z wyciskami napisowymi i dekoracyjnymi. Cześć z nich przedstawia charakterystyczne rozety o formie identycznej z rozetami na oprawie Lubrańskiego [il. 4]. Tożsamość narzędzia, z którego wykonano zdobienia mogłaby zatem świadczyć o jego przejściu do poznańskiego warsztatu działającego w latach 40. XVI w. z pracowni funkcjonującej przed 1520 r. Należy jednak mieć na uwadze możliwość wędrówki tego narzędzia w ciągu pierwszych czterech dekad XVI w. pomiędzy warsztatami z zupełnie innych ośrodków wytwórczości. Mogło się to dokonać w różny sposób, np. poprzez zakup wyposażenia po zmarłym rzemieślniku, bądź poprzez przejęcie go w spadku, po którym nabywca zmienił miasto działalności.

Toteż, mimo owej przesłanki do poznańskości oprawy biskupiego woluminu, jej wykonanie w tym mieście pozostawić należy w sferze swobodnych hipotez. Jednocześnie wskazane jest przyjrzenie się głównemu polskiemu centrum introligatorstwa późnośredniowiecznego i renesansowego, jakim był Kraków. W mieście tym bowiem J. Lubrański bywał relatywnie często i długo z racji swych obowiązków kościelnych i dyplomatycznych, co umożliwiało mu nie tylko nabywanie ksiąg, ale i korzystanie z usług tamtejszych introligatorów ${ }^{35}$. Dla wymagającego bibliofila, którego gusta z pewnością kształtowały oprawy z jakimi stykał się podczas włoskich studiów i późniejszych podróży dyplomatycznych do Italii, istotny był fakt, że krakowscy introligatorzy oferowali już od 2. połowy XV w. oprawy naśladujące włoskie dzieła renesansowe ${ }^{36}$. W uwrażliwieniu biskupa na

${ }^{34} \mathrm{O}$ działalności Jana Patruusa zob. m.in.: Wojciechowska, $Z$ dziejów, s. 18-19, 30, 33, 40; Pilichowski, Z dziejów, s. 54-58, 61-62; EWOK, szp. 1021; M. Krynicka, Oprawy książkowe z herbami ostatnich Jagiellonów w zbiorach Muzeum Narodowego w Krakowie, „Rozprawy i Sprawozdania Muzeum Narodowego w Krakowie”, XII (1980) s. 54, przyp. 70; A. Kawecka-Gryczowa, Biblioteka ostatniego Jagiellona. Pomnik kultury renesansowej, Wrocław-Warszawa-Kraków-GdańskŁódź, 1988, s. 96; A. Wagner, Introligatorstwo poznańskie jako historyczno-artystyczna «terra incognito», w: Sztuka w Wielkopolsce, red. M. Błaszczyński, B. Górecka, M. Górecki, A. Paradowska, Poznań 2013, s. 78-81.

${ }^{35}$ Częstotliwość i długość krakowskich pobytów Lubrańskiego jako bpa poznańskiego analizuje K. Lutyński, Kościelna działalność Jana Lubrańskiego jako biskupa poznańskiego, KMP, 2 (1999) s. 74-77.

${ }^{36} \mathrm{O}$ italianizmie w krakowskim introligatorstwie XV-XVI w. zob. m.in.: Sztuka w Krakowie w latach 1350-1550. Wystawa urzadzona w sześćsetletnia rocznice zatożenia Uniwersytetu Jagiellońskiego, Muzeum Narodowe w Krakowie 1964, s. 48-50, il. 99; A. Lewicka-Kamińska, Rzut oka na rozwój oprawy książkowej w Krakowie, „Roczniki Biblioteczne”, 16 (1972) z. 1-2, s. 52, 54-55, il. 2-3, 5-10; I. Schunke, Krakauer Frührenaissanceeinbände, „Gutenberg Jahrbuch”, 1973, s. 429434, il. 1-3; M. Krynicka, Bucheinbände, w: Polen im Zeitalter der Jagiellonen, 1386-1572, Schal- 
ideę italianizacji szaty zewnętrznej prywatnych ksiąg z pewnością niebagatelną rolę odegrała przyjaźń łącząca go od czasów studenckich ze słynnym bibliofilem i humanistą krakowskim - Mikołajem Czepielem (Czeplem) z Poznania ${ }^{37}$. Ten drugi zaś nie tylko posiadał pokaźny księgozbiór, w którym wyróżniały się druki ze słynnej oficyny weneckiej Alda Manucjusza, ale też oddawał do oprawy swe woluminy w lokalnych warsztatach kopiujących rozwiązania formalne z ówczesnych opraw włoskich, zwłaszcza w typie alla greca ${ }^{38}$. Łatwo wyobrazić sobie, że J. Lubrański podczas swych krakowskich pobytów odwiedzał przyjaciela, zapoznając się z jego bibliofilskimi okazami. Ponadto jest wysoce prawdopodobne, że znał on także oprawy książek należących do wspomnianego już bpa Drzewickiego. Te zaś, jak pozwala sądzić np. zachowany do dziś egzemplarz ze zbiorów w Pommersfelden $^{39}$ i Gnieźnie ${ }^{40}$, wykonywane były również w Krakowie wedle wzorów dekoracyjnych renesansowego introligatorstwa Italii.

Okolicznością sprzyjającą J. Lubrańskiemu w stykaniu się z oryginalnymi oprawami włoskimi był import ksiąg do Krakowa. Na szczególne podkreślenie zasługuje tu aktywna działalność Alda Manucjusza, który we współpracy z Janem Silviusem Siculusem, Constanzo Clarettim, Janem Hallerem i prawdopodobnie też Hieronimem Wietorem eksportował do Krakowa liczne druki głównie ze swej oficyny, rozprowadzane potem wśród studentów i profesury Akademii oraz innych odbiorców o humanistycznych zainteresowaniach ${ }^{41}$. Biskup miał zatem możliwość zakupywania tzw. aldów u któregoś z krakowskich bibliopoli. Zapewne oryginalne oprawy aldyńskie miały druki, które biskup nabył bądź otrzymał w darze od słynnego impresora. Najpewniej należało do nich dzieło Waleriusza Maxima wydane w 1503 lub 1504 r., w którym Aldo zawarł dedykację dla biskupa, zabiegając w ten sposób o jego wsparcie w poszukiwaniach zaginionych rękopisów, znajdujących się rzekomo w mitycznej wieży w Dacji ${ }^{42}$. Deklarację pomo-

laburg 1986, s. 497-502, 507-508; J. Storm van Leeuwen, The Golden Age of Bookbindings in Cracow 1400-1600, Kraków 2011, s. 15-21, 24-30, 32 i inne.

${ }^{37}$ Łempicki, Polskie koneksje, s. 55; Lewicka-Kamińska, Renesansowy, s. 5, 7, 13, 28-29; Marciniak, Biblioteka, s. 124; J. Wiesiołowski, Polscy wspóltowarzysze studiów Jana Lubrańskiego, KMP, 2 (1999) s. 50-51, 55.

${ }^{38}$ Wiadomo, że Czepiel już podczas włoskich studiów w latach 70. XV w. miał na prośbę znajomego z Polski oddać zakupione książki do oprawienia italiano more w ręce tamtejszego introligatora (Lewicka-Kamińska, Renesansowy, s. 39; taż, Rzut oka, s. 52); na temat italianizujących opraw z księgozbioru Czepla zob.: Lewicka-Kamińska, Renesansowy, s. 34-41; tabl. 12-14, 17-19; B. Nuska, Polski wplyw na formowanie się czeskiej oprawy ksiązowej, „Ze skarbca kultury”, 16 (1964) s. 148-149, 179; J. Storm van Leeuwen, The Golden, s. 28-29, kat./tabl. 34-35.

${ }^{39}$ W. Schonath, Polnische Bucheinbände in der Graf von Schönbornschen Schloßbibliothek Pommersfelden, „Archiv für Geschichte des Buchwesens”, Bd VI, 1966, szp.316, 339, il. 4.

${ }^{40}$ P. Pokora, Pontificale Romanum z 1520 roku z biblioteki prymasa Macieja Drzewickiego. O odnalezieniu jednego z zaginionych klejnotów Biblioteki Katedralnej w Gnieźnie, „Biblioteka”, 17 (2013) s. 42-46, il. 1-3.

${ }^{41}$ Lempicki, Polskie koneksje, s. 51-54; Lewicka-Kamińska, Renesansowy, s. 37; Rokosz, Wenecka, s. 184-192.

${ }^{42}$ Łempicki, Polskie koneksje, s. 47-49; Rokosz, Wenecka, s. 103, 176-182, il. 39a-b; J.S. Gruchała, Iucunda Familia Librorum. Humaniści renesansowi w świecie książki, Kraków 2002, s. 101- 
cy w tej materii J. Lubrański złożył Manucjuszowi w 1502 r., gdy spotkał się $\mathrm{z}$ nim podczas pobytu w Padwie ${ }^{43}$. Być może z książkowymi podarunkami wiąże się list, jaki J. Lubrański wysłał w 1507 r. do Alda, dziękując w gorących słowach za jego hojnośćc ${ }^{4}$.

Za krakowskim pochodzeniem oprawy biskupa może przemawiać oznaczenie jej superekslibrisem, jako że w tamtejszym introligatorstwie już w 3. ćwierci XV w. popularyzować się zaczął zwyczaj oznaczania własności ksiąg w ten sposób. Początkowo były to herby lub napisy wykonywane za pomocą uniwersalnych narzędzi zdobniczych jak noże (oprawy tzw. nacinane) i tłoki ${ }^{45}$. Od 4. ćwierci XV w. używano natomiast miniaturowych herbów wyciskanych w rozmaitych miejscach okładzin w otoczeniu motywów typowo zdobniczych [il. 5a, b] ${ }^{46}$. Wraz z ustalaniem się włoskich formuł dekoracyjnych opraw, przynajmniej od początku XVI w. superekslibrisy zyskiwały jednak coraz bardziej eksponowane miejsca w polu zwierciadła, a nawet w jego centrum. Wciąż jednak odznaczały się one małymi rozmiarami i prostą formą, typową dla heraldyki polskiej przełomu gotyku i renesansu. Typ ten reprezentują na przykład dwie z trzech odmian superekslibrisów stosowanych od pierwszej dekady XVI w. przez Mikołaja Czepiela [il. 5c $]^{47}$. Owe znaki własnościowe, ukazywane zarówno na gotycko-renesansowych jak i wyraźnie italianizujących oprawach, nie mogły ujść uwagi zaprzyjaźnionego z nim biskupa. Innym, współczesnym J. Lubrańskiemu bibliofilem z kręgów elity kościelnej, oznaczającym swe księgi przypuszczalnie już od pierwszej dekady XVI w. miniaturowymi superekslibrisami $\mathrm{w}$ przynajmniej czterech odmianach był bp Erazm Ciołek. Dowodzą tego oprawy inkunabułów i postinkunabułów zachowane m.in. w Bibliotece Czartoryskich w Krakowie, Bibliotece Raczyńskich w Poznaniu, czy też we wrocławskim Ossolineum, na których w różnych miejscach

103. Według Rokosza (Wenecka, s. 198-199, 259) Lubrański posiadał przynajmniej 4 aldy, do których należy dodać - nie wykazany w inwentarzu pośmiertnym - druk słynnego wenecjanina z dedykacją dla hierarchy.

${ }^{43}$ Łempicki, Polskie koneksje, s. 47-49; Hajdukiewicz, Księgozbiór, s. 18, 41; Rokosz, Wenecka, s. 178; Marciniak, Biblioteka, s. 119; Gruchała, Iucunda, s. 101-102.

${ }^{44}$ Łempicki, Polskie koneksje, s. 49; Rokosz, Wenecka, s. 182-183, il. 40; Marciniak, Biblioteka, s. 119.

${ }^{45}$ Zob. np.: K. Piekarski, O superexlibrisie polskim, w: Katalog wystawy pięknej książki polskiej, urzadzonej z powodu IV. Zjazdu Bibljotekarzy Polskich $w$ Warszawie 31 maja - 15 czerwca, Warszawa 1936, s. 30; Lewicka-Kamińska, Rzut oka, s. 52-53, il. 1-2; taż, Nieznane ekslibrisy polskie XVI wieku w Bibliotece Jagiellońskiej, Kraków 1974, s. 9; Poolse Boekbindkunst 1400-1800. Uit de Jagielloński Bibliotheek Kraków, Koninklijke Bibliotheek, Den Haag 1990, kat./il. 24; A. Wagner, Supralibros in Polen in der Zeit vom 15. bis zur ersten Hälfte des 17. Jahrhunderts im Lichte neuerster Forschungen, „Einband Forschung“, 34 (2014) s. 54-55, il. 1.

${ }^{46}$ Zob. np.: K. Piekarski, Superexlibrisy polskie od XV do XVIII wieku, z. I, Kraków 1929, s. 1 (nie num), tabl. 18, 29-31; J. Zathey, A. Lewicka-Kamińska, L. Hajdukiewicz, Historia Biblioteki Jagiellońskiej, T. I, 1364-1775, red. I. Zarębski, Kraków 1966, s. 150-151; Lewicka-Kamińska, Nieznane, s. 9; Poolse, kat./il. 32; Wagner, Supralibros, s. 55-56, il. 2.

${ }^{47}$ Zob. np.: Lewicka-Kamińska, Renesansowy, s. 36, 39-40, tabl. 2/1-3, 12, Zathey, LewickaKamińska, Hajdukiewicz, Historia, s. 152-153; Storm van Leeuwen, The Golden, kat./tabl. 34-35. 
górnych i dolnych okładzin wyciśnięto mały herb pod infułą i pastorałem [il. 5e] ${ }^{48}$. Jakkolwiek styl dekoracji większości znanych dziś opraw ksiąg Ciołka jest w pełni gotycki, lub też gotycko-renesansowy, to tarcza superekslibrisów ma specyficzną formę testa di cavallo, wyróżniającą renesansową heraldykę włoskąa ${ }^{49}$. Ponadto bp E. Ciołek ozdabiał swe księgi charakterystycznym superekslibrisem o italianizującej formie, w którym na tarczy herbowej widnieje zarówno godło jak i insygnia biskupie, wkomponowane w jej górną częśś ${ }^{50}$.

Niestety mgliście rysuje się obecna wiedza o praktyce oznaczania ksiąg superekslibrisami przez innych polskich dostojników kościelnych w końcu XV i pierwszych latach XVI w. I tak np. trudno orzec czy już wówczas swe księgi oznaczał nimi biskup, a później prymas Jan Łaski (1456-1531). W literaturze podkreśla się wprawdzie jego chłodny stosunek do poezji i dzieł humanistycznych, co odróżniało go od wykształconych na włoskich uczelniach bpów Lubrańskiego, Drzewickiego czy też Krzyckiego ${ }^{51}$. Z drugiej jednak strony wiadomo, że najpóźniej w 1514 r. dysponował on swoim superekslibrisem w prostokątnej ramce, $\mathrm{z}$ herbem rodowym Korabitów oraz herbem arcybiskupstwa gnieźnieńskiego pod insygniami tego hierarchy ${ }^{52}$. W świetle zachowanych woluminów dopiero w 2. dekadzie XVI w. superekslibrisami zaczął oznaczać swe księgi bp Piotr Tomicki, należący do tylko nieco młodszej niż Lubrański, Ciołek i Łaski generacji dygni-

${ }^{48}$ R. Kotula, Katalog inkunabutów Bibljoteki Fundacji Wiktora hr. Baworowskiego we Lwowie, Lwów 1932, kat. 38, tabl. nie num. po s. 18; Katalog inkunabułów Biblioteki Zakładu im. Ossolińskich we Wrocławiu, na podstawie materiatów K. Piekarskiego, opr. A. Kawecka-Gryczowa, Wrocław 1956, kat. 270. Zob. też: A. Chmiel, Z dawnych opraw introligatorskich, „Exlibris”, 1 (1917) z. 1, s. 15, il. 9; Wagner, Nieznana oprawa, s. 50-52, il. 7; tenże, Oprawa z superekslibrisami biskupa Erazma Ciołka $w$ zbiorach Biblioteki Raczyńskich w Poznaniu, „Ecclesia. Studia z Dziejów Wielkopolski", 8 (2013) s. 101-123, il. 1-3, 5-6, 9-15.

${ }^{49}$ Zob. np.: G. di Crollalanza, Enciclopedia araldico-cavalleresca. Prontuario nobiliare, Bologna 1964, s. 581; G. Santi-Mazzini, Araldica. Storia, linguaggio, simboli e significati dei blasoni e delle armi, Milano 2003, s. 53. Problem stosowania tego typu tarczy w polskich superekslibrisach zob.: Wagner, Nieznana oprawa, s. 26-29, 49-52, il. 1-2, 7-8, 10, 12; tenże, Oprawa z superekslibrisami, s. 106-108, il. 1-3, 5-6, 9-15.

${ }^{50}$ Tłok do odbijania tego superekslibrisu zachował się w zbiorach Muzeum Narodowego w Krakowie (zob. np.: Chmiel, $Z$ dawnych, s. 14-15, il. 8; Kraków. Europejskie miasto prawa magdeburskiego 1257-1791, Katalog wystawy, Muzeum Historyczne Miasta Krakowa, Kraków 2007, nr kat./il. IX. 31); zob. też. Formanowicz, Katalog, nr kat. 136/2.

${ }^{51}$ Hajdukiewicz, Księgozbiór, s. 82-83; P. Tafiłowski, Jan Laski (1456-1531) kanclerz koronny i prymas Polski, Warszawa 2007, s. 289, 340-343, 435 i inne. Z drugiej strony, o „wybitnej indywidualności bibliofilskiej" Łaskiego pisze Nuska, Polski, s. 180. Należy też podkreślić upodobanie Łaskiego do renesansowych dzieł sztuki, co zaowocowało m.in. zamówieniem u Jana Florentczyka - rzeźbiarza na dworze węgierskim w Budzie - 6 płyt epitafijnych dla katedry gnieźnieńskiej i wawelskiej, o pionierskiej na ziemiach polskich, antykizującej formie; zob. np. H. Kozakiewiczowa, Mecenat Jana Łaskiego (z zagadnień sztuki renesansowej w Polsce), „Biuletyn Historii Sztuki”, 23 (1961) nr 1, s. 4, 7-9, 16, il. 2-6; Tafiłowski, Jan Easki, s. 406-416.

${ }^{52}$ Katalog inkunabułów Biblioteki Zakładu im. Ossolińskich we Wrocławiu, kat. 220a, tabl. XIII; Wszystkie modlitwy Rzeczypospolitej. Katalog wystawy, red. D. Sidorowicz-Mulak, Zakład Narodowy im. Ossolińskich, Wrocław 2009 nr kat./il. 66. 
tarskich bibliofilów ${ }^{53}$. Nastąpiło to zatem po wielu latach gromadzenia ksiąg, nabywanych przez niego w pierwotnych oprawach bądź oddawanych do oprawy bez superekslibrisu ${ }^{54}$.

Powyższe realia mogły stanowić zachętę dla J. Lubrańskiego by korzystać z usług krakowskich introligatorów, oferujących na przełomie XV i XVI w. wyroby o coraz silniejszym pierwiastku renesansowym i ozdabiane superekslibrisami. Sprzyjała temu również relatywnie duża dostępność ksiąg sprowadzanych do Krakowa z różnych ośrodków drukarstwa, w tym z Italii i Niemiec. Dlatego też, wobec obecnego stanu wiedzy o rynku introligatorsko-księgarskim w Poznaniu i Krakowie w XV i XVI w., jako bardziej prawdopodobne jawi się wykonanie omawianej oprawy właśnie w stolicy państwa. Stanowisko to wspiera przegląd dorobku krakowskiego introligatorstwa od końca XV w. do 1520 r., dostarczający szeregu przykładów dzieł o formie podobnej do lubranscianum.

W pierwszej kolejności, typowe dla niego są materiały zastosowane we włocławskim zabytku. Odnosi się to zarówno do bukowych desek, brązowej skóry bydlęcej, którą powleczono połowę powierzchni okładzin, jak też mosiężnych zapinek, pokrytych wytłaczaną dekoracją. Niestety, trudno orzec skąd pochodzi papier użyty na wyklejki i antefolium. Znajdujący się na przedniej wyklejce filigran jest zbyt nieczytelny by łączyć go z konkretną papiernią (możliwa jest tylko jego ogólnikowa identyfikacja jako głowy wołu prawdopodobnie z koroną zamkniętą). Także drugi - dobrze widoczny - filigran z karty antefolium nie ułatwia identyfikacji papierni. Ukazuje on bowiem głowę wołu z długim krzyżem, po którym wije się wąż [il. 6]. Motyw ten należał zaś do szeroko rozpowszechnionych w papiernictwie europejskim XV-XVI w., czego dowodem jest grubo ponad dwieście wariantów zaprezentowanych w fundamentalnym opracowaniu Picarda ${ }^{55}$. Wariant z omawianej oprawy nie został w nim jednak zarejestrowany. Formy bardziej zbliżone do tej z antefolium mają filigrany wykazane przez Franciszka Piekosińskiego w rodzimym materiale papierniczym z ostatnich dwóch dekad XV w. i początków XVI w. O ile jednak niemal analogiczne okazują się motywy węża i krzyża to zazwyczaj znacznie prostsze kształty mają wołowe głowy ${ }^{56}$. Z kolei znane z papierów używanych na początku XVI w. w krakowskich drukarniach Hallera, Wietora i Unglera motywy głowy wołu z podwójnym krzyżem owiniętym przez węża są zaś ikonograficznie zbyt odmienne od filigranów z lubranscianum by traktować je za wytwory tej samej papierni ${ }^{57}$. Wśród materiału

${ }^{53}$ Zob. np: J. Grycz, Z dziejów i techniki książki, Wrocław 1951, il. 99; Hajdukiewicz, Księgozbiór, s. 182-187 (zob. też katalog); A. Bochnak, K. Buczkowski, Rzemiosło artystyczne w Polsce, Warszawa 1971, tabl. 137-138.

${ }^{54}$ S. Brzeziński, Biblioteka biskupa-podkanclerzego Piotra Tomickiego, Warszawa 1939, s. 14, 16; Hajdukiewicz, Księgozbiór, s. 182, 186-187.

${ }^{55}$ Die Ochsenkopfwasserzeichen, 3. Teil, Findbuch II, 3, bearbeitet von G. Piccard, Stuttgart 1966, rys. 111-367.

${ }^{56}$ F. Piekosiński, Wybór znaków wodnych z XV stulecia, z. I, Kraków 1896, rys. 1088-1097, 1099, 1102-1105, 1109, 1111, 1116-1119.

${ }^{57}$ J. Siniarska-Czaplicka, Katalog filigranów czerpalni Rzeczypospolitej zebrany z papieru druków tłoczonych w latach 1500-1800, Łódź 1983, rys. 1072-1080. 
zarejestrowanego przez Briqueta najbardziej podobny okazuje się filigran powiązany z Dreznem w $1513 \mathrm{r}^{58}$ Być może zatem mimo ewidentnych i w jego przypadku różnic $\mathrm{z}$ filigranem $\mathrm{z}$ oprawy, papier antefolium można by wywieść $\mathrm{z}$ kręgu saskiego? Brak identycznych filigranów nakazuje uznać tę kwestię za otwartą.

Typowa dla krakowskiego introligatorstwa od schyłku XV do schyłku 2. dekady XVI w. jest dekoracja opraw, w których ogólny schemat kompozycyjny wraz z zasobem motywów zdobniczych świadczą o przenikaniu się pierwiastka gotyckiego i renesansu włoskiego. W omawianym dziele dominuje jednak ten pierwszy - reprezentowany kompozycją całości i niemal wszystkimi składnikami dekoracji, wyciskanymi z tłoków i radełek - co stanowiłoby wskazówkę, że powstało ono raczej bliżej początku aniżeli końca wspomnianego przedziału czasowego. Wyróżnikiem krakowskich opraw jest relatywnie prosty schemat kompozycyjny ram wyznaczonych strychulcem, w których mieszczą się zmultiplikowane (rzadziej naprzemienne) wyciski rozet o rozmaitej formie, zaś w wydzielonych narożnikach - ślepe bądź złocone wyciski herbów lub gmerków. Pod koniec XV w. upowszechnia się też pod wpływem niemieckim wydzielanie osobnych, poziomych listew ramy górnej okładziny, w której wyciśnięty jest zazwyczaj złocony tytuł dzieła ${ }^{59}$. O ile w końcu XV w. absolutnie dominuje tu tekstura gotycka, to wraz z początkiem następnego stulecia powoli zaczyna ją wypierać antykwa, wyraźnie ewoluująca w kierunku form coraz bliższych liternictwu włoskiego renesansu.

Motyw arabeskowy o linearnej formie, wypełniający wewnętrzną ramę włocławskiej oprawy, zaczerpnięty został przez krakowskich introligatorów z dzieł włoskich (zwłaszcza weneckich), choć nie wykluczone, że na jego spopularyzowanie miało wpływ również tamtejsze iluminatorstwo i grafika książkowa ${ }^{60}$. Od około $1500 \mathrm{r}$. trwał on - właściwie w niezmiennej formie - w repertuarze stołecznych rzemieślników aż do lat 40. XVI w. ${ }^{61}$. Godne uwagi jest też zróżnicowanie grubości pionowych oraz poziomych odcinków arabeskowej ramy. Wyraźna przewaga tych drugich ma swe uzasadnienie nie tylko w wydłużonych proporcjach płaszczyzny okładziny skórzanej (co można było zmienić poprzez wydłużenie 15403.

${ }^{58}$ C. M. Briquet, Les filigranes, wyd. Martino Publishing 2007 (reprint wyd.: Paris 1907), rys.

${ }^{59}$ Zob. np.: M. Krynicka, Oprawy introligatora Monogramisty J. L. w zbiorach Biblioteki Czartoryskich w Krakowie, „Rozprawy i Sprawozdania Muzeum Narodowego w Krakowie”, 9 (1967) s. 85-87, il. 60, 62-64, 69; Poolse, kat./il. 37-38, 40, 50, 58, 64-65, 70 i inne

${ }^{60}$ Zob. np.: T. De Marinis, La legatura artistica in Italia nei secoli XV e XVI, Volume II, Firenze 1960, tabl. CCXVI/1249, CCCLXXII/2073 i inne. O występowaniu rozmaitych form tego motywu we włoskim iluminatorstwie i grafice książkowej świadczy np. dekoracja inicjału nieokreślonego toskańskiego rękopisu iluminowanego z 3. ćwierci XV w. (Ameisenowa, Rękopisy, il. 56) i zdobienia drzeworytniczej karty tytułowej dzieła Bartłomieja Montagnany, Consilia, wydanego w Wenecji w 1499 (L. Jarzębowski, Biblioteka Mikołaja Kopernika, Toruń 1971, il. 13).

${ }^{61}$ L. Dobrzyńska-Rybicka, Dwie wielkopolskie biblijoteki klasztorne, „Zapiski Muzealne”, 1917, s. 10, tabl. I/2, i1. 11, 27b; Storm van Leeuwen, The Golden, kat./il. 30, 35, 36, 42. Zob. też Chmiel, Z dawnych, s. 16, tabl. IV/11c; EWOK, tabl. 45/3b (tamże oryginalny tłok z tym motywem, używany przez krakowskich introligatorów), a ostatnio 122 Aukcja Antykwaryczna, 22. X. 2011, Krakowski Antykwariat Naukowy, kat./il. 457. 
zwierciadła), ale też w odwołaniu do rozwiązań włoskich, wywodzących się $z$ tradycji islamskiej ${ }^{62}$. Jako wyróżnik krakowskiego introligatorstwa wczesnorenesansowego uważany jest podział wąskiego zwierciadła na trzy pola wypełnione naprzemiennymi motywami ${ }^{63}$. Z nim z kolei wiąże się charakterystyczna dla stołecznych introligatorów wertykalizacja zdobień zwierciadła, obejmujących różnorakie motywy (w tym superekslibrisowe herby). Swe apogeum osiągnęła ona na początku XVI w. w tzw. „motywie drzewa” na oprawach ksiąg wójtowskich, wykonywanych przez Monogramistę J L ${ }^{64}$.

Szczególną popularnością wśród introligatorów krakowskich przynajmniej od ostatniej dekady XV w., aż do ostatniej ćwierci XVI w. cieszył się też minuskułowy chrystogram w okrągłej glorii promienistej. Najczęściej wyciskano go z osobnych tłoków przedstawiających monogram w pierścieniu oraz tłoków z prostymi i falującymi promieniami o różnej wielkości ${ }^{65}$. Rzadziej zaś - np. w warsztacie Jerzego Moellera - był wyciskany z jednego dużego tłoku bądź plakiety $^{66}$. W niektórych przypadkach, jak np. na oprawie wykonanej po $1515 \mathrm{r}$. przez Stanisława z Białej, Macieja z Przasnysza bądź nieokreślonego introligatora z ich kręgu, zdają się być one wręcz replikami tłoka użytego w oprawie J. Lubrańskiego [il. 7] (sygn. Biblioteki Towarzystwa Naukowego Płockiego: XVI, 743). Zastosowany $\mathrm{w}$ dekoracji dolnej okładziny lubranscianum wielokrotny wycisk radełka $\mathrm{z}$ charakterystycznym ornamentem floralno-zoomorficznym miał w sztuce około 1500 r. długą tradycję, łączącą się zwłaszcza z iluminatorskimi droleries. Jednakże zestawienie czworonogów z konarami o uciętych gałęziach oplecionymi liśćmi akantu były szczególnie popularne w krakowskim introligatorstwie, w którym występowały w różnych wariantach ${ }^{67}$.

Mimo powyższych pokrewieństw między oprawą księgi biskupiej, a dorobkiem warsztatów krakowskich, stwierdzić należy, że wśród materiału zabytkowe-

${ }^{62}$ Zob. np.: G. Bologna, Legature, Milano 1998, il. na s. 89-90; R. Miriello, Legature riccardiane, I, Firenze 2008, kat./il. 6, 19-21, 25-26, 78 i inne.

${ }^{63}$ Schunke, Krakauer, s. 430, il. 1.

${ }^{64}$ Zob. np.: L. Lepszy, Przemyst artystyczny i handel, „Rocznik Krakowski”, 6 (1904) s. 290, il. 60; Sztuka w Krakowie, kat. 251; Krynicka, Oprawy, s. 81-83, 85, 94, il. 59, 63.

${ }^{65}$ Problem ten porusza Nuska, Polski, s. 145, 148, 152, il. 1 (autor wywodzi ów motyw z gotyckich monstrancji); zob. też np.: Lewicka-Kamińska, Rzut oka, il. 5; Poolse, kat./il. 90, Storm van Leeuwen, The Golden, s. 20. Często w centrum okładzin ukazywano chrystogram w pierścieniu wyzbytym promieni, z kolei promienie wykorzystywano jako dekorację towarzyszącą np motywom figuralnym, zob. np.: Dobrzyńska-Rybicka, Dwie, il. 27b; Lewicka-Kamińska, Rzut oka, il. 4; Krynicka, Bucheinbände, kat./il. 554;

${ }^{66}$ Zob. Poolse, kat./il. 90; Storm van Leeuwen, The Golden, nr kat./tabl. 47; tenże motyw prawdopodobnie na oprawie w: A. Biały, Opis i katalogowanie zabytkowych opraw ksiażkowych na przykładzie obiektów z zabytkowej biblioteki na Jasnej Górze w Częstochowie, w: Od ksiązki dawnej do biblioteki wirtualnej - przeobrażenia bibliologii polskiej. Na marginesie trzydziestolecia Instytutu Informacji Naukowej i Bibliologii UMK w Toruniu, red. D. Degen, M. Fedorowicz, Toruń 2009, il. nie num. na s. 129. Taki wycisk również na oprawie druku z 1546 r. o sygn. XVI. F. 4394 w Bibliotece Wyższego Seminarium Duchownego im. Księży Chodyńskich we Włocławku.

${ }^{67}$ Zob. np.: Chmiel, Z dawnych, s. 10, il. 1, tabl. I-II, V; Storm van Leeuwen, The Golden, s. 21, kat./il. 34, 36-37; Wagner, Motywy, s. 144-145, il. 5a-c. 
go przeanalizowanego w fachowej literaturze brakuje obiektu, którego kompozycja dekoracji i motywy zdobnicze pozwalałby na jednoznaczne powiązanie z wykonawcą lubranscianum. Wobec wciąż znikomo poznanego dorobku introligatorstwa polskiego schyłku XV i początków XVI w., oznaczałoby to identyfikację dzieła dotąd nieznanego anonimowego mistrza działającego w Krakowie, ewentualnie w Poznaniu. Jego bliższe określenie prezentuje się jako wyzwanie na przyszłość, do podjęcia którego skłania odkrycie w Archiwum Archidiecezjalnym w Gnieźnie - już po oddaniu niniejszego tekstu do druku - kolejnej oprawy oznaczonej superekslibrisem bpa J. Lubrańskiego ${ }^{68}$. Cechy formalne tego, znanego mi $\mathrm{z}$ fotografii, dzieła wskazują jednoznacznie na wykonanie w tej samej pracowni, w której powstała oprawa ze zbiorów włocławskich. Ponadto, wyciśnięty na niej motyw tarczy herbowej z małpą wpatrującą się w lustro stanowić może dowód na krakowskie wykonawstwo, za czym przemawia zarejestrowanie innych dzieł $\mathrm{z}$ tym motywem w zbiorach inkunabułów Biblioteki Jagiellońskiej w Krakowie $^{69}$.

Problemu nastręcza określenie dokładnego czasu powstania oprawy. Data wydrukowania inkunabułu jest bowiem za wczesna, by łączyć z nią charakterystyczną kompozycję dekoracji okładzin oraz radełko i zasób tłoków. Niewiele wnoszą też przybliżone daty powstania europejskich filigranów podobnych do tych $\mathrm{z}$ lubranscianum. Również pokrewieństwa formalne $\mathrm{z}$ wyrobami introligatorów krakowskich pozwalają jedynie na zawężenie czasu powstania dzieła do pierwszych dwóch dekad XVI w. Wskazówką o dyskusyjnym znaczeniu jest oszczędna, półskórkowa forma oprawy. $Z$ jednej strony mogłaby ona bowiem wskazywać na okres, gdy J. Lubrański musiał bardziej liczyć się z kosztami zamówienia opraw. Ten zaś przypadałby na lata poprzedzające hipotetyczne objęcie - pierwszego w jego karierze - biskupstwa płockiego, co nastąpiło w listopadzie $1497 \mathrm{r}^{70}$. Wiadomo jednak, że oprawy analogicznego typu zamówił w trzydzieści parę lat później wytrawny, a jednocześnie zamożny bibliofil bp Tomicki ${ }^{71}$. Być może zatem decydującą winna okazać się wskazówka związana z superekslibrisem wyzbytym insygniów biskupich, co sygnalizowałoby oprawienie księgi przed listopadem 1497 r. Warto jednak nadmienić, że wśród starszej generacji hierarchów kościel-

\footnotetext{
${ }^{68}$ Dokonał tego zespół badaczy inwentaryzujących tamtejsze stare druki pod kierunkiem dra Piotra Pokory.

${ }^{69} \mathrm{~W}$. Wisłocki, Incunabula typographica Bibliothecae Universitatis Jagellonicae Cracoviensis, Cracoviae 1900, s. 25, 42, 97, 244, 461 (badacz określił wykonawcę opraw z tym motywem jako „Introligator de signo Simiae in scuto”. Warto nadmienić, że jakkolwiek dokonane przez Wisłockiego liczne i pochopne atrybucje dzieł introligatorskich wyimaginowanym introligatorom na podstawie tłoków stosowanych na oprawach krakowskich XV-pocz. XVI w. okazały się bałamutne, to w rzeczonym przypadku badacz wykazał się dobrą intuicją).

${ }^{70}$ Nie jest pewne czy Lubrański ostatecznie objął to biskupstwo, zob. Pakulski, Krag, s. 29-30; tenże, Ród Godziembów w średniowiecznej Polsce. Studium genealogiczne, Torun 2005, s. 117.

${ }^{71}$ Hajdukiewicz, Księgozbiór, s. 184, 184; półskórkowe oprawy ksiąg z legatu biskupa dla Akademii Krakowskiej, wykonane w rok po jego śmierci, wiążą się już ze skromnymi możliwościami finansowymi akademickiego zleceniodawcy, zob.: Hajdukiewicz, Księgozbiór, s. 185-186; Poolse, kat./il. 80; Storm van Leeuwen, The Golden, kat./il. 43.
} 
nych uzupełnienie swego herbu insygniami biskupimi nie musiało być wcale takie oczywiste, skoro np. bp Wojciech Jastrzębiec (†1436), czy też bp Zbigniew Oleśnicki $(\uparrow 1455)$ zrezygnowali ze zlecenia swym iluminatorom umieszczenia takich motywów nad herbami w przynajmniej niektórych manuskryptach, fundowanych przez siebie bądź posiadanych na własność ${ }^{72}$. Nawet bp Jakub Sienna $(\dagger 1480)$ na jednym z wykwintnych, renesansowych rękopisów przywiezionych przez siebie z Italii, ograniczył się do zlecenia namalowania herbu rodowego w antykizującym wieńcu $^{73}$. W czasach współczesnych J. Lubrańskiemu postawę taką reprezentował zaś najprawdopodobniej bp Andrzej Krzycki, za czym przemawia oprawa ze zbiorów olsztyńskiego „Hosianum”, należąca hipotetycznie do tego dygnitarza i oznaczona jedynie herbem Kotwic ${ }^{74}$.

W obliczu obecnego poziomu wiedzy o księgozbiorze bpa J. Lubrańskiego oraz realiach introligatorskich w Królestwie Polskim epoki późnego gotyku i wczesnego renesansu, należałoby uznać oprawę ze zbiorów włocławskich za dzieło anonimowego introligatora krakowskiego, lub - co znacznie mniej prawdopodobne - poznańskiego, wykonane w pierwszym dwudziestoleciu XVI w.

Nie wiadomo jak długo księga znajdowała się w prywatnym księgozbiorze hierarchy. Jednoznacznej odpowiedzi na tę kwestię nie daje jego inwentarz pośmiertny, jako że wzmiankowana w nim Biblia mogła być zupełnie innym woluminem. Rozważenia wymaga zatem możliwość przekazania księgi za życia J. Lubrańskiego do Kazimierza Biskupiego, gdzie w latach 1504-1520 sfinansował on odnowienie kościoła parafialnego, a w 1514 r. - wraz z bratem, Mikołajem wybudowanie kościoła i klasztoru bernardynów ${ }^{75}$. Wiadome jest, że zarówno Lubrański jak i prymas Łaski wsparli tamtejszą, zakonną librarię bliżej nieokreśloną liczbą ksiąg ${ }^{76}$. Tom Biblii musiał zaś należeć do kanonicznych pozycji w klasztornym księgozbiorze. O tym, że księga ta na pewno znalazła się w Kazimierzu świadczy nota zapisana na karcie antefolium piękną, późnogotycką teksturą kaligraficzną: „Iste liber est comparatus p[erillustrum?] Reuere[n]dissimu[m] Joha[n]nem de Lubranijecz Episcopu[m] Poznanie[n]sem Fundatorem loci Cazimiriensis $\cdot 1 \cdot 5 \cdot 3 \cdot 3 \cdot$ " [il. 8]. Wskazuje ona na fakt znajdowania się woluminu w tymże roku w Kazimierzu, nie wiadomo jednak od kiedy. Mając na uwadze, że

${ }^{72}$ Zob. E. Potkowski, Książka rękopiśmienna w kulturze Polski, Warszawa 1984, il. 25; Miodońska, Małopolskie, il. V, 89, 98-100, 105-108 i inne.

${ }^{73}$ Z. Ameisenowa, Rękopisy i pierwodruki iluminowane Biblioteki Jagiellońskiej, WrocławKraków 1958, kat. 40, il. 54.

${ }^{74}$ J. Wojtkowski, Katalog druków XVI wieku Biblioteki Wyższego Seminarium Duchownego Metropolii Warmińskiej ,Hosianum” w Olsztynie, Lublin 2012, nr kat. 1300 (autor pomija pierwotną proweniencję woluminu, wzmiankując jedynie ,kartusz herbowy”); Wagner, Oprawa z superekslibrisami, s. 107, przyp. 24.

${ }^{75}$ Z. Chodyła, Czasy nowożytne (1504-1793), w: Dzieje Kazimierza Biskupiego, Część I, Monografia, praca zbiorowa pod red. Z. Chodyły, Kazimierz Biskupi-Poznań 1993, s. 79-81, il. 5, na okładce; Architektura gotycka w Polsce, red. T. Mroczko, M. Arszyński, II, Katalog Zabytków, red. A. Włodarek, Warszawa 1995, s. 104-105; P. Budzan, A. Karłowska-Kamzowa, Działalność fundacyjna biskupa poznańskiego Jana Lubrańskiego, KMP, 2 (1999) s. 97-98.

${ }^{76}$ Tafiłowski, Jan Laski, s. 24. 
kwestie spadkowe po śmierci biskupa zostały uregulowane w 1521 r., wydaje się mało prawdopodobne, by po ponad dekadzie kapituła katedralna znalazła powód do przekazania jednej z pozostałych po nim ksiąg kazimierskim bernardynom. Był to już bowiem czas działalności Neacademii, zapewne jawiącej się katedralnemu klerowi jako godniejsze dla niej lokum. Nic zaś nie wiadomo by biskup zamierzał przekazać pośmiertnie jakąkolwiek księgę do Kazimierza na mocy np. testamentu. Takowego zresztą nie sporządził.

Druga zapiska proweniencyjna o treści „Liber loci Cazimiriensis” znajduje się na górnym obcięciu kart książki. Teksturowy krój liter wyrazów pozwala na przypisanie jej temu samemu skrybie, który naniósł formułkę z antefolium, o czym przesądzają np. zaokrąglone brzuszki „a”, „,b”, płynny, migdałowaty kształt „o”, czy też długi i cienki ogonek końcowego „s". Bardziej użytkowy aniżeli pamiątkowy charakter napisu spowodował jednak rezygnację skryby z nadania literom finezyjnej ozdobności, co odnosi się zwłaszcza do pierwszych liter wyrazów. Jak wykazała kwerenda wśród włocławskich inkunabułów zapiskę o analogicznej treści i kroju liter noszą też górne obcięcia kart innych inkunabułów (np. sygn. XV. F. 1266). Świadczyłoby to o podjętej w kazimierskiej librarii w $1533 \mathrm{r}$. akcji oznaczania własności większej liczby - bądź nawet wszystkich - tamtejszych ksiąg. O tym, że pochodziły one z rozmaitych źródeł zdają się świadczyć ich oprawy, wykonane w różnych warsztatach i wyzbyte znaków własnościowych zarówno bpa J. Lubrańskiego jak i wspomnianego drugiego dobrodzieja biblioteki prymasa Łaskiego ${ }^{77}$.

Woluminy te, wraz z około 270 innymi księgami, przetrwały w kazimierskiej bibliotece do 1905 r., skąd przewiezione zostały do biblioteki seminaryjnej we Włocławku. Potwierdzają to noty zapisane przez księdza Stanisława Chodyńskiego na dwóch inkunabułach (XV.F.1244, XV.F.1273): „Z Kazimierza 1905 30/IX x. Chodyński”78. Akt ten ma źródło w rozporządzeniu władz carskich z 1865 r., o przejmowaniu księgozbiorów ze skasowanych klasztorów w zaborze rosyjskim, w wyniku czego do biblioteki seminaryjnej we Włocławku trafiły stosunkowo liczne zbiory m.in. z Chocza, Kalisza, Konina i Sieradza ${ }^{79}$. Tam znaj-

${ }^{77}$ Warto nadmienić, że na karcie przybyszowej jednego z inkunabułów kazimierskich, przechowywanego we Włocławku (Guillermus, Postilla super epistolas..., stara sygn. Inc. F 1001), znajduje się wpis introligatora: „Istum librum introligavit frater Nicodemus de Thvlijszkow pro loco Cazijmijrensi Anno Domini 1526 oretur pro eo". Jednakże analiza wykonanej przez niego oprawy jednoznacznie wskazuje, że nie był autorem oprawy lubranscianum (zob. J. Wojtkowski, Glosy i drobne teksty polskie do 1550 roku z inkunabułów Kalisza, Kazimierza Biskupiego, Koła, Sieradza i Warty, Poznań 1965, kat. 27/4).

${ }^{78}$ Klasztor bernardyński w Kazimierzu Biskupim zlikwidowano w 1898 r., a opiekę nad nim przejęli księża diecezjalni. Za udzielenie szczegółowych informacji na ten temat dziękuję ks. Kazimierzowi Rulce, dyrektorowi Biblioteki Wyższego Seminarium Duchownego im. Księży Chodyńskich we Włocławku.

${ }^{79} \mathrm{O}$ przejmowaniu przez włocławską bibliotekę seminaryjną księgozbiorów poklasztornych zob. np: K. Rulka, Biblioteka seminaryjna, w: Od wieków kształci pasterzy. Wyższe Seminarium Duchowne we Włocławku, Włocławek 1994, s. 86-87 (autor nie wymienia Kazimierza Biskupiego); B. Iwańska-Cieślik, Zarys dziejów Biblioteki Wyższego Seminarium Duchownego we Włocławku, „Zapiski Kujawsko-Dobrzyńskie. Oświata i nauka”, 20 (2005) s. 157-158 (autorka nie wymienia 
dowały się do II wojny światowej, gdy wraz z resztą najcenniejszych zbiorów bibliotecznych seminarium zostały wywiezione przez Niemców do Poznania, a następnie do Bytynia. Stamtąd - ponownie via Poznań - wróciły w 1945 r. wraz z częścią paleotypów, które uniknęły zniszczenia i kradzieży, do Włocławka ${ }^{80}$. Od tego czasu wchodzą w skład jednego z najbogatszych zbiorów inkunabułowych w Polsce ${ }^{81}$.

O szczególnej wartości historycznej biskupiej księgi przesądza nie tyle jej metryka i zawartość treściowa, jako że oprawiony inkunabuł jest reprezentowany w samych polskich kolekcjach bibliotecznych kilkoma egzemplarzami. Wartość tę determinuje proweniencja woluminu, wiążąca się ze słynną postacią rodzimego humanizmu. Wśród rozpoznanych zaledwie czterech (a z uwzględnieniem ostatnio odkrytego woluminu w Gnieźnie - pięciu), ksiąg należących do bpa J. Lubrańskiego, jest jedną z dwóch ozdobionych superekslibrisem. Ten zaś należy do najwcześniejszych znaków własnościowych książki stosowanych w elitarnym kręgu dygnitarskich bibliofilów polskich pierwszych dwóch dekad XVI w.

słowa kluczowe: Bp Jan Lubrański, bibliofilstwo, humanizm, introligatorstwo w Krakowie, introligatorstwo w Poznaniu, oprawy książkowe, superekslibris, protoekslibris, ekslibris, Aldus Manucjusz, bp Erazm Ciołek, prymas Jan Łaski, Kazimierz Biskupi, Włocławek

Kazimierza Biskupiego); K. Rulka, Księgozbiór Biblioteki Wyższego Seminarium Duchownego we Włocławku i jego opracowanie w XIX i XX wieku, ,Acta Universitatis Nicolai Copernici, Bibliologia V, Nauki Humanistyczno-Społeczne, z. 376”, 2006, s. 210-211, 222.

${ }^{80} \mathrm{O}$ dramatycznych losach ksiąg seminaryjnych podczas II wojny światowej w m.in.: S. Librowski, Materiały do dziejów diecezji włocławskiej czasu wojny 1939-1945, seria 1 - ogólna, ABMK, 38 (1979) s. 255-256; K. Rulka, Straty Biblioteki Seminarium Duchownego im. Księży Chodyńskich w czasie II wojny światowej, „Kronika Diecezji Włocławskiej”, 78 (1995) nr 10, s. 437-442.

${ }^{81} \mathrm{O}$ historii i zbiorach biblioteki w m.in.: Iwańska-Cieślik, Zarys dziejów, s. 153-170; Rulka, Księgozbiór, s. 209-224. 


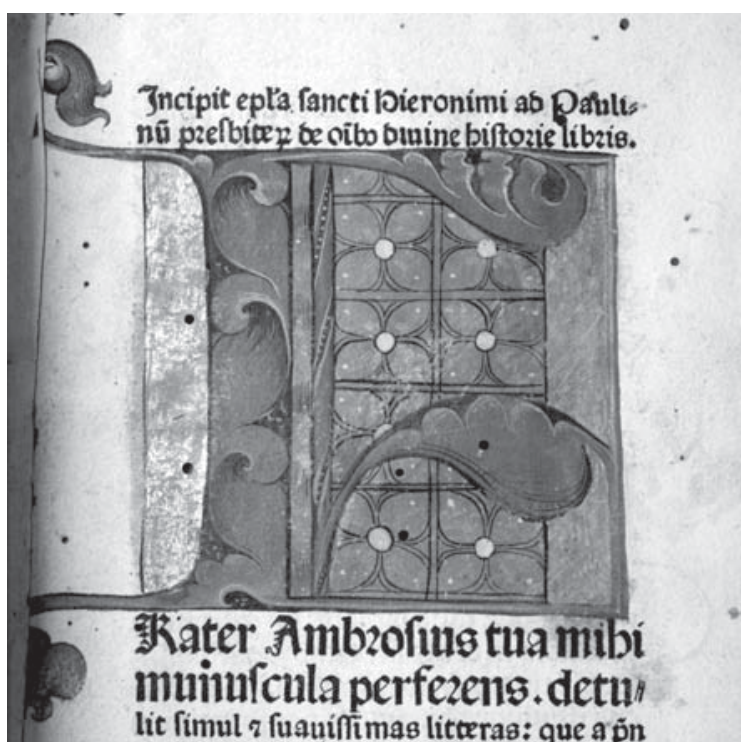

il. 1. Inicjał iluminowany „F” na pierwszej stronie inkunabułu z księgozbioru bpa Jana Lubrańskiego, po 1487; zbiory Biblioteki WSD we Włocławku; fot. Arkadiusz Wagner/

photo 1. The illuminated initial „F” on the first page of the incunabulum from Bishop Jan Lubrański’s library, after 1487; the collections of the Library of the Seminary in Włocławek; photographer: Arkadiusz Wagner

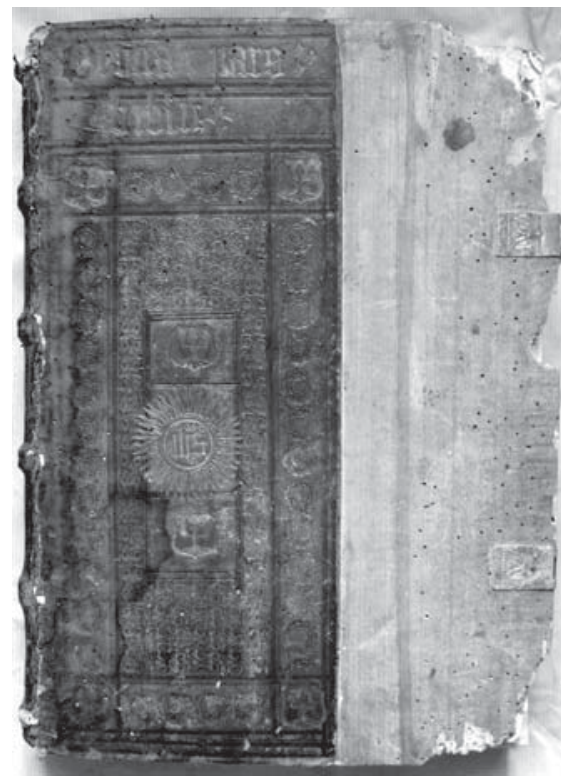

il. 2. Oprawa inkunabułu z księgozbioru bpa Jana Lubrańskiego (górna okładzina), prawdopodobnie introligator krakowski, 1 dwudziestolecie XVI w.; zbiory Biblioteki WSD we Włocławku; fot. Arkadiusz Wagner/

photo 2. The incunabulum binding from Bishop Jan Lubrański's library (upper binding), probably a bookbinder from Cracow, first twenty years of the sixteenth century; the collections of the Library of the Seminary in Włocławek; photographer: Arkadiusz Wagner 


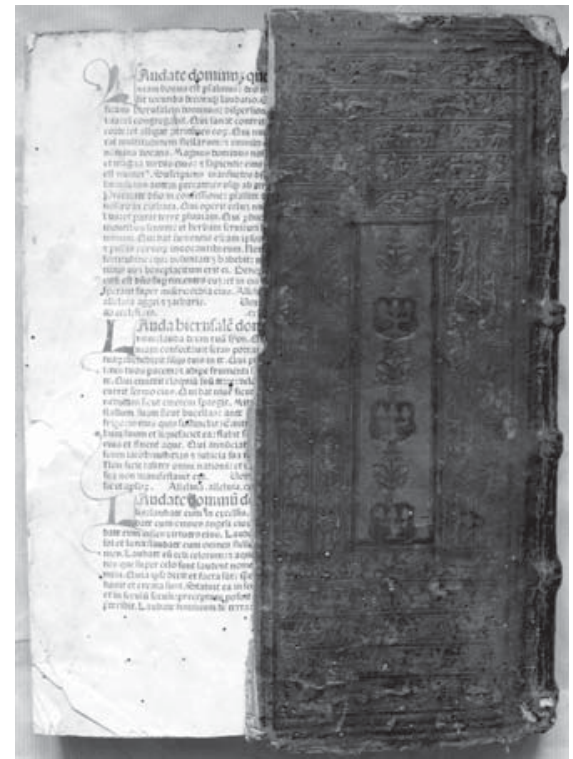

il. 3. Oprawa inkunabułu z księgozbioru bpa Jana Lubrańskiego (dolna okładzina), prawdopodobnie introligator krakowski, 1 dwudziestolecie XVI w.; zbiory Biblioteki WSD we Włocławku; fot. Arkadiusz Wagner/

photo 3. The incunabulum binding from Bishop Jan Lubrański’s library (lower binding), probably a bookbinder from Cracow, first twenty years of the sixteenth century; the collections of the Library of the Seminary in Włocławek; phographer: Arkadiusz Wagner

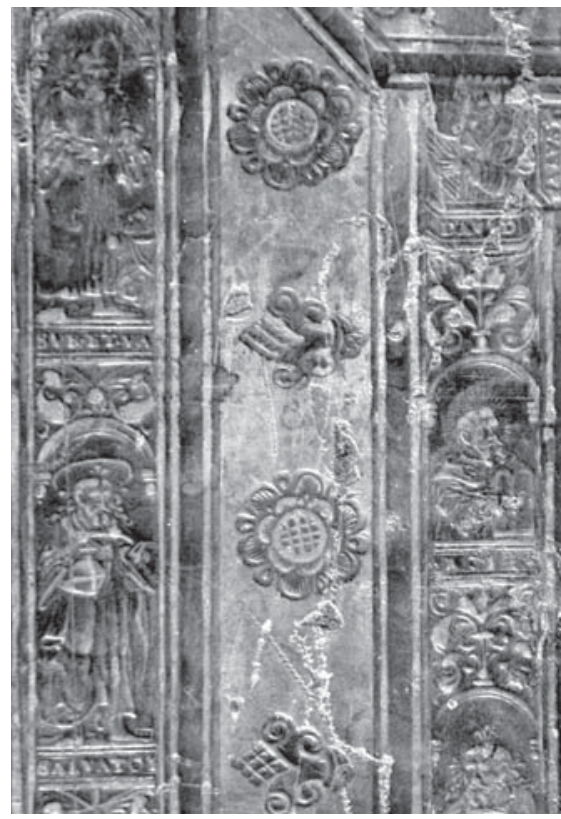

il. 4. Fragment dekoracji oprawy poznańskiej, prawdopodobnie warsztat Jana Patruusa lub introligatora z jego kręgu, 1546; zbiory Biblioteki Towarzystwa Naukowego Płockiego; fot. Arkadiusz Wagner/

photo 4. The fragment of the binding decoration from Poznań, probably Jan Patruusa's workshop or a bookbinder from his circle, in 1546; the collections of the Library of the Płock Scientific Society; photographer: Arkadiusz Wagner 
il. 5. Przykłady wczesnych polskich superekslibrisów/ photo 5. Examples of early Polish supralibros:

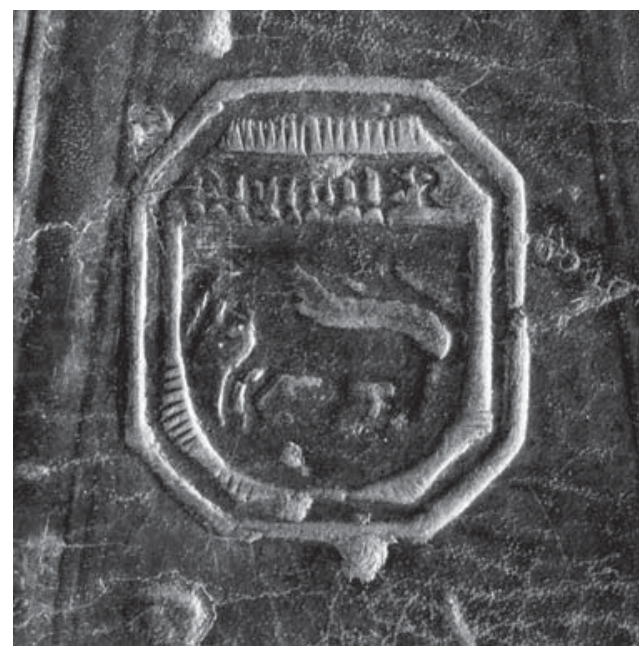

a. Arnolfa z Mirzyńca, ok. 1484; zbiory i fot. Biblioteki Jagiellońskiej/

a. Arnolf from Mirzyniec, about 1484; the collections and photos of the Jagiellonian Library

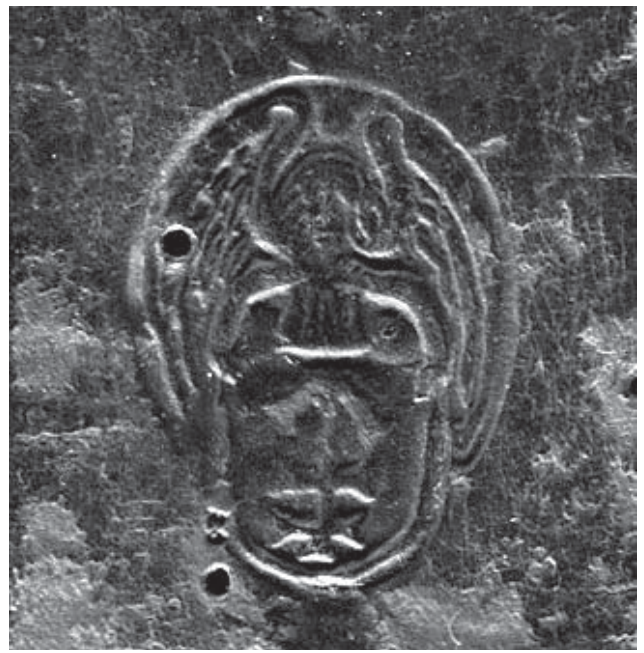

b. Piotra Świętopełka z Zambrzecza, ok. 1480; zbiory i fot. Biblioteki Jagiellońskiej/

b. Piotr Świętopełk from Zambrzecze, about 1480; the collections and photos of the Jagiellonian Library 


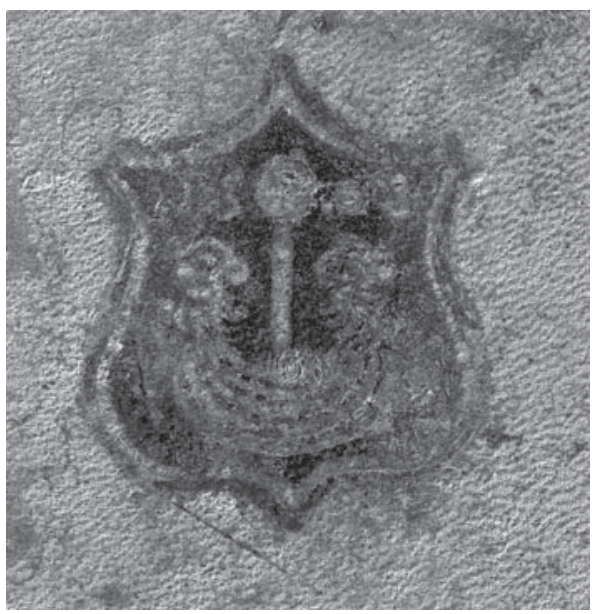

c. Mikołaja Czepiela, 1508; zbiory i fot. Biblioteki Jagiellońskiej/

c. Mikołaj Czepiel, 1508; the collections and photos of the Jagiellonian Library

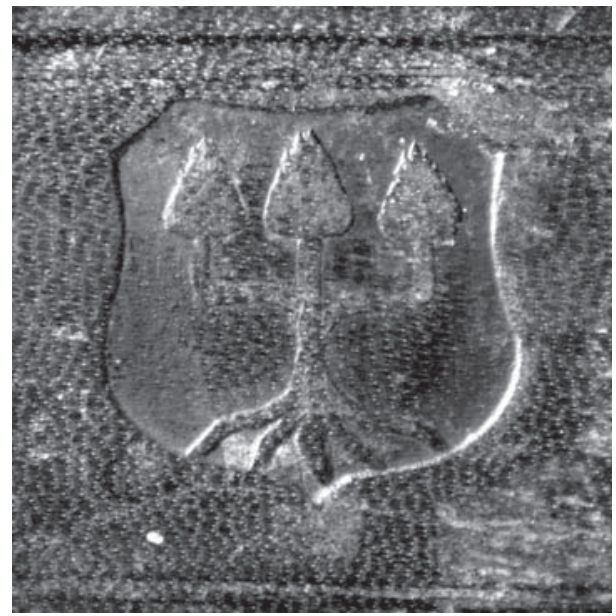

d. bpa Jana Lubrańskiego, 1 dwudziestolecie XVI w.; zbiory Biblioteki WSD we Włocławku/

d. Bishop Jan Lubrański, the first twenty years of the sixteenth century; the collections of the Library of the Seminary in Włocławek 


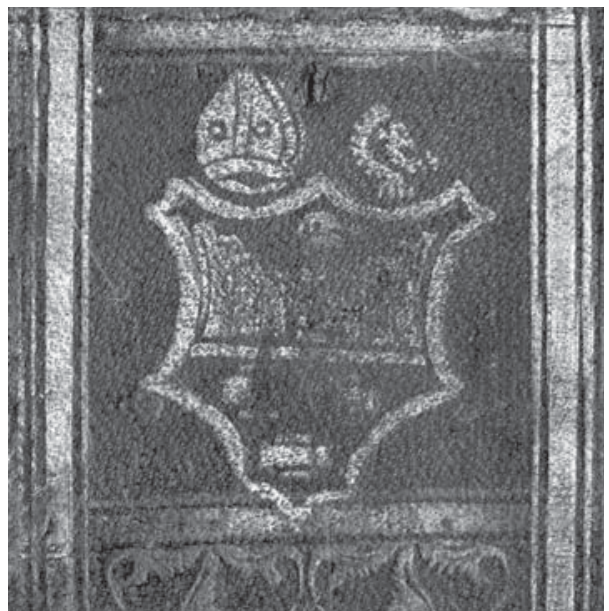

e. bpa Erazma Ciołka, 2 dekada XVI w.; zbiory i fot. Biblioteki Ossolineum we Wrocławiu/

e. Bishop Erazm Ciołek, the second decade of the sixteenth century; the collections and photographs of the Ossolineum Library in Wrocław

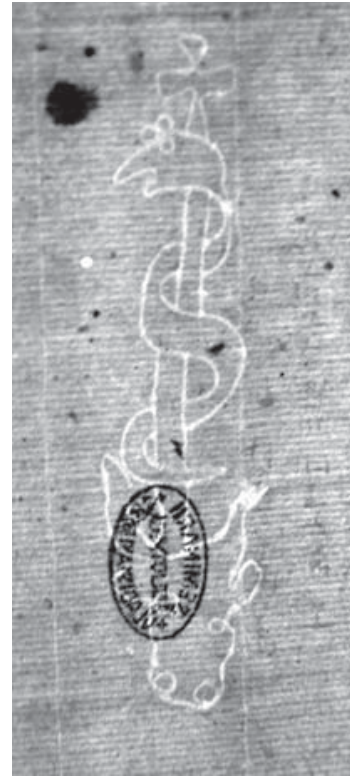

il. 6. Filigran na antefolium inkunabułu z księgozbioru bpa Jana Lubrańskiego, koniec XV-1 dwudziestolecie XVI w., zbiory Biblioteki WSD we Włocławku, fot. Arkadiusz Wagner/

photo 6. Filigran on the antefolium of the incunabulum from Bishop Jan Lubrański's library, the end of the fifteenth -first twenty years of the sixteenth century, the collections of the Library of the Seminary in Włocławek, photographer: Arkadiusz Wagner 


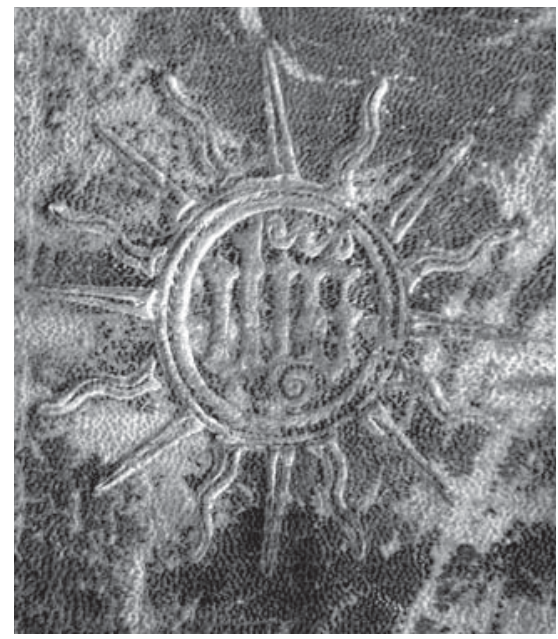

il. 7. Chrystogram w glorii promienistej na oprawie krakowskiej, po 1515, zbiory Biblioteki Towarzystwa Naukowego Płockiego, fot. Arkadiusz Wagner/

photo 7. Christogram in radiant glory on the binding of Cracow, after 1515, the collections of the Library of the Płock Scientific Society, photographer: Arkadiusz Wagner

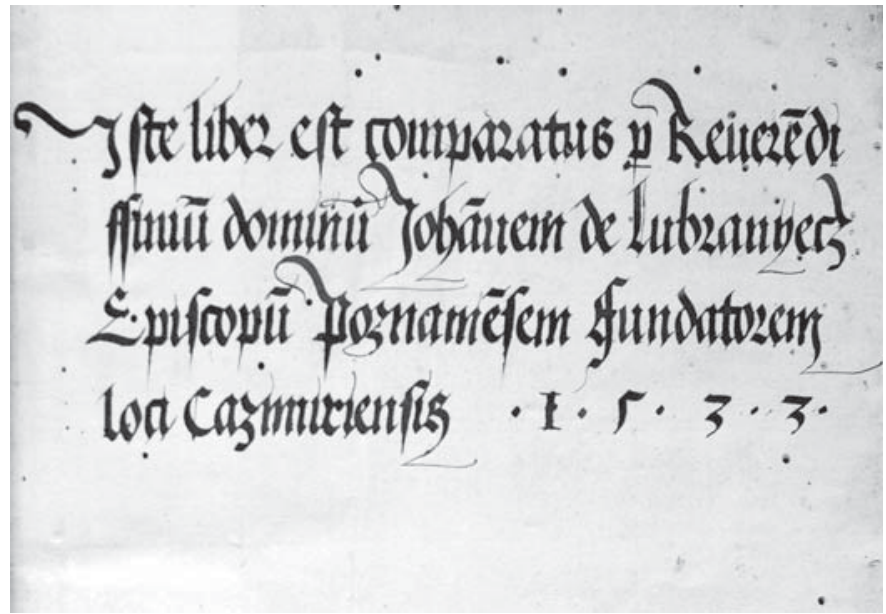

il. 8. Wpis okolicznościowy na antefolium inkunabułu z księgozbioru bpa Jana Lubrańskiego, 1533; zbiory Biblioteki WSD we Włocławku; fot. Arkadiusz Wagner/

photo 8. Occasional entry on the antefolium of the incunabulum from Bishop Jan Lubrański's library, 1533; the collections of the Library of the Seminary in Włocławek; photographer: Arkadiusz Wagner 


\title{
INCUNABULUM WITH BISHOP JAN LUBRAŃSKI'S SUPRALIBROS AGAINST THE BACKGROUND OF BOOKBINDING IN CRACOW AND POZNAŃ IN THE LATE FIFTEENTH CENTURY AND THE BEGINNING OF THE SIXTEENTH CENTURY
}

\begin{abstract}
Summary
The article focuses on the binding of the incunabulum from the book collection of one of the greatest Polish Renaissance bibliophiles, Jan Lubrański Bishop of Poznań. The great value of this historical monument, discovered in 2012 in the Library of the Seminary in Włocławek, results from the fact that it is one of the few volumes that remained from hierarch's extensive book collection, and also the only one, so far discovered, marked with his supralibros. The article starts with a biographical outline of Bishop Lubrański, with special attention paid to his bibliophilic activity. Then, the author presents a detailed formal and stylistic analysis of the binding against the background of bookbinding of the Polish leading centers in this field in the late fifteenth and sixteenth centuries. The result is the hypotheses concerning the time and place of its creation, which point to the unknown bookbinding workshop in Cracow or Poznan, operating in the first two decades of the sixteenth century. Finally, the author attempts to trace the history of the book from the time of Lubrański up to its discovery in the collections of Włocławek.
\end{abstract}

keywords: Bishop Jan Lubrański, bibliophilia, humanism, bookbinding in Cracow, bookbinding in Poznań, book bindings, supralibros, protoekslibris, ex libris, Aldus Manucjusz, Bishop Erazm Ciołek, Primate Jan Łaski, Kazimierz Biskupi, Włocławek 